УДК 339.138

Лялюк Алла, кандидат економічних наук, доцент, Волинський національний університет імені Лесі Українки, доцент кафедри підприсмництва і маркетингу, м. Луцьк\$ ORCID ID 0000-0002-4889-0511

https://doi.org/10.29038/2411-4014-2020-04-46-53 e-mail: allalyalyuk@gmail.com

\title{
РОЛЬ МІЖНАРОДНОГО МАРКЕТИНГУ В ГЛОБАЛЬНОМУ ПІДПРИЄМНИЦТВІ
}

\begin{abstract}
У статті досліджено погляд різних авторів на трактування терміну «міжнародний маркетинг»; розглянуто види міжнародного маркетингу; показано описано переваги та недоліки міжнародного маркетингу; наголошено на важливості глобального міжнародного менеджменту; представлено процес міжнародного маркетингового стратегічного планування; описано приклади впливу маркетингових стратегій на розвиток глобального підприємництва; доведено, що успіх глобального маркетингу компанії проявляється через репутацію товарного бренду; наголошено про важливість в глобальному підприємництві вивчення національної культури країни, на яку планує вийти підприємство із своєю продукцією; запропоновані заходи щодо покращення глобального підприємництва за допомогою міжнародного маркетингу
\end{abstract}

Ключові слова: міжнародний маркетинг, глобальне підприємництво, маркетингове стратегічне планування, маркетингові технології, міжнародне маркетингове середовище

Лялюк Алла, кандидат экономических наук, доцент, Волынский национальный университет имени Леси Украинки, доцент кафедры предпринимательства и маркетинга, г. Луцк

\section{РОЛЬ МЕЖДУНАРОДНОГО МАРКЕТИНГА В ГЛОБАЛЬНОМ ПРЕДПРИНИМАТЕЛЬСТВЕ}

В статье исследованы взгляд разных авторов на трактовку термина «международный маркетинг»; рассмотрены виды международного маркетинга; показано на преимущества и недостатки международного маркетинга; подчеркнута важность глобального международного менеджмента; представлено процесс международного маркетингового стратегического планирования; описано примеры влияния маркетинговых стратегий на развитие глобального предпринимательства; доказано, что успех глобального маркетинга компании проявляется через репутацию товарного бренда; отмечено о важности в глобальном предпринимательстве изучения национальной культуры страны, на которую планирует выйти предприятие со своей продукцией; предложены меры по улучшению глобального предпринимательства с помощью международного маркетинга

Ключевые слова: международный маркетинг, глобальное предпринимательство, маркетинговое стратегическое планирование, маркетинговые технологии, международное маркетинговая среда

Lialiuk Alla, Associate Professor, Economics and Security of Enterprise Department, Lesia Ukrainka Volyn National University, Associate Professor, Ph.D. in Economics

Lutsk 


\section{ROLE OF INTERNATIONAL MARKETING IN GLOBAL ENTREPRENEURSHIP}

The statistic has a glance at the interpretation of the term "international marketing"; view of international marketing; it is shown that the passages and shortcomings of international marketing are described. Vitchiznyans and foreign sciences are responsible for the role of marketing functions in the management of all kinds of people in the global market. So, the results show that the marketing function in the development of financial indicators, the efficiency of new products with customers, and the profitability of new products on the market.

The order of sorts of naukovtsi talk about those that are less important for marketing as functions, and more for the meaning of the rules, so that marketing is transformed into an independent process.

Naked on the importance of global international management; presents the process of international marketing strategic plan. Internal drivers - ti, which resemble a company and, in such a rank, are controlled by a server, such as a global capacity and functionality of a company, as well as financing and international availability of kervniks.

On the other hand, the name of the drivers is not controlled by the brand, but it does not add a global strategy to the state of affairs. Among these factors is the global economy, culture, political and legal systems and technologies. The system of global marketing has been discussed, and I have a lot of respect for the fallow land: Global Marketing Performance.

It is said about the importance in the global education of the national culture of the country, on the plan to start the enterprise out of its products; Proposed come back to the global community for help with international marketing

Key words: international marketing, global enterprise, marketing strategic planning, marketing technologies, international marketing medium

Постановка наукової проблеми та її значення. Стрімкий розвиток глобалізації, який в останні десятиліття супроводжується появою мільярдів нових клієнтів і нових конкурентів на світовому ринку, революційні зміни в технології комунікацій, а також подальша економічна лібералізація зумовили до переоцінки ролі міжнародного маркетингу в глобальному підприємництві..

Аналіз досліджень цієї проблеми. Серед науковців, які досліджують пов’язані з міжнародним маркетингом актуальні проблеми глобалізації економічного розвитку, слід назвати виділити відомих вітчизняних і зарубіжних учених-економістів: Кальченко Т. В., Філіпенко А. С..та ін.[1, 8]. Теоретичні засади концепції підприємництва, розробка й обгрунтування нових науково-методичних положень щодо формування інноваційної моделі розвитку України та її регіонів на основі реалізації підприємницького чинника досліджували Храпкіна В. В., Проданова Л. В., Котляревський О. В. [3, 5]. Серед українських та зарубіжних авторів найбільший внесок у вивчення проблем міжнародного маркетингу зробили Циганкова Т. М. [9], Федорович Р. В. [6], Супрун С. Д., Стратійчук В. М. [7], Корж М. В. [4], Ковінько О. М.[2], Нгуєн Хоанг Тьєн, Фан Пхунг Фу та Данг Тхі Пхуонг Чі (Nguyen Hoang Tien, Phan Phung Phu and Dang Thi Phuong Chi) [10] Є. Горська (Elena Horská) [17], Дж.Шес, Е. Парвейтіар (Sheth J., Parvatiyar A.) [14], Дж .Е. Квелч, Е. Дж. Гофф (Quelch, E. J., Hoff A. J.) [15] та інші. Однак, досить часто у визначеннях вітчизняного маркетингу та міжнародного маркетингу побутує твердження, що різниця між ними полягає в тому, що маркетингова діяльність здійснюється не в одній країні. Ця часто, здавалося б, незначна різниця обумовлює складність у в міжнародних маркетингових операціях. Тому виникає потреба у додаткому осмисленні ролі міжнародного иаркетингу у глобальному підприємництві.

Мета і завдання статті. Метою статі с дослідити погляди різних авторів на трактування терміну «міжнародний маркетинг»; розглянути види міжнародного маркетингу; представити процес міжнародного маркетингового стратегічного планування; описати приклади впливу маркетингових стратегій на розвиток глобального підприємництва та запропоновані заходи щодо покращення глобального підприємництва за допомогою міжнародного маркетингу

Виклад основного матеріалу. У науковій літературі пропонує кілька різних визначень міжнародного маркетингу:

Міжнародний маркетинг передбачає операції на ряді ринків іноземних країн, на яких, крім неконтрольованих змінних, також регулюються фактори (у формі структури витрат і цін, можливості рекламної та дистрибутивної інфраструктури) суттєво відрізняються між одними ринками. Подібні відмінності призводять до ускладнень міжнародного маркетингу [17], 
Міжнародний маркетинг визначається як ведення бізнесу з метою планування, ціноутворення, просування та спрямування лінійки товарів та послуг для клієнтів або користувачів у більш ніж одній країні для отримання прибутк у[10].

Міжнародний маркетинг складається з висновків та задоволення глобальних потреб споживачів краще, ніж конкуренція, як внутрішня, так і міжнародна, та координація маркетингової діяльності в умовах глобального середовища [11].

Міжнародний маркетинг фокусується на необхідності створювати, спілкуватись та доставляти цінність на міжнародному рівні [12].

Визначення Американської асоціації маркетингу (AMA) - міжнародний маркетинг як багатонаціональний процес планування та реалізації концепції, ціноутворення, просування та розповсюдження ідей, товарів та послуг для створення обмінів, що задовольняють індивідуальні та організаційні цілі [17]. Слово багатонаціональність означає, що маркетингові заходи проводяться в декількох країнах, i їх слід якось координувати між державами. Однак це визначення має деякі обмеження. Визначення наголошує на взаємозв'язку між споживачем та його окремими цілями та організаціями з їхніми цілями. По суті, він не охоплює питань маркетингу від бізнесу до бізнесу, який передбачає транзакцію між двома організаціями, хоча, у світі урядів міжнародного маркетингу, квазідержавні установи та суб'єкти, що шукають прибуток та некомерційні організації, часто є покупцями .

Міжнародний маркетинг набагато складніший, ніж внутрішній, тому що маркетолог стикається 3 двома або більше наборами некерованих змінних з різних країн, які походять з різних культурних, правових, політичних та грошових систем У таблиці 1. наведено огляд переваг та недоліків міжнародного маркетингу.

Таблиия 1

Потенційні переваги та ризики міжнародного маркетингу

\begin{tabular}{|c|c|}
\hline Переваги & Недоліки \\
\hline $\begin{array}{l}\text { - можливість створити економію на масштабі } \\
\text { - можливість зростання, якщо внутрішня торгівля } \\
\text { обмежена } \\
\text {-можливість уникнути жорсткої конкуренції вдома } \\
\text { - створити імідж міжнародного бренду або } \\
\text { забезпечити міжнародні послуги } \\
\text { транснаціональних клієнтів } \\
\text { - можливість розпоряджатися великими запасами } \\
\text { - можливість збільшити прибуток, використовуючи } \\
\text { надлишкову потужність } \\
\text { - можливість продовжити життєвий цикл товару, } \\
\text { якщо це інакше, ніж у вітчизняній країні } \\
\text { - географічна диверсифікація зменшує специфічні для } \\
\text { країни ризики }\end{array}$ & $\begin{array}{l}\text { - ризик нестабільності урядів } \\
\text { - ризик нестабільності валют } \\
\text { складні вимоги до входу, } \\
\text { різністандарти, законодавство та } \\
\text { нормативні акти } \\
\text { - труднощі з розумінням місцевої } \\
\text { культури, звичаї, цінності та норми } \\
\text { - труднощі із входом до місцевого каналу } \\
\text { розподілу }\end{array}$ \\
\hline
\end{tabular}

Вітчизняні та зарубіжні науковці $[6-7,9,10,14-15,16]$ стверджують, що маркетингові функції повинні грати першочергову роль в управлінні відносинами між споживачами (клієнтами) на глобальному ринку. Так, результати їх досліджень показують, що маркетингова функція сприяє зростанню фінансових показників, ефективності відносин 3 клієнтами та рентабельності впровадження на ринок нових товарів (послуг).

Поряд 3 цим науковці наголошують про те, щоб менше було маркетингу як функцій, а більше як сукупність значень і правил. Тобто перетворення маркетингу у самостійний процес. Відповідно, виникає важливе питання, що вимагає відповіді - який конкретний внесок маркетингової функції в отриманні прибутку компанії від діяльності на глобальному ринку. Відображаючи такий інтерес ще у 1996-1998 роках Науково-дослідний інститут маркетингових наук провів дослідження на тему «Маркетинг як функція, пов'язана з ринком, як процес і бачення в майбутньому». Водночас інші 
зарубіжні науковці називають це як «міжфункціональне розповсюдження маркетингової діяльності» та прогнозують, що це призведе до зменшення попиту на подальші функції [1] .

Ефективність орієнтації на ринок залежить від наявності потужних функцій, в тому числі і маркетингу. 3 огляду на вищенаведене, заслуговує уваги розроблена зарубіжними науковцями Н. Х. Тьєн, Ф. П. Фу та Д. Т. П. Чі (Nguyen Hoang Tien, Phan Phung Phu and Dang Thi Phuong Chi) концепція, яка визначає обсяг маркетингової функції і як вона працює в багатофункціональному світі ринково-орієнтованої компанії. В основі їх дослідження покладена ідея про те, що маркетингова функція полегшує зв'язок між клієнтами і різними важливими процесами всередині підприємства. Однак, самі науковці підкреслюють, що вони досліджують не лише цінність маркетингової функції, але і її масштаби [10].

Кожна сфера маркетингу матиме різну роль у стратегії глобального підприємництва. Спосіб представлення міжнародного маркетингу залежить від рівня залученості компанії на міжнародний ринок. У табл.2 наведені види міжнародного маркетингу.

Таблиця 2

\section{Види міжнародного маркетингу}

\begin{tabular}{|c|l|}
\hline $\begin{array}{c}\text { Вид міжнародного } \\
\text { маркетингу }\end{array}$ & \multicolumn{1}{|l}{ Характеристика } \\
\hline Експортний маркетинг & $\begin{array}{l}\text { компанія продає свої товари / послуги за національні або } \\
\text { політичні межі. }\end{array}$ \\
\hline $\begin{array}{c}\text { Маркетинг у приймаючій } \\
\text { країні (в яку експортують) }\end{array}$ & $\begin{array}{l}\text { маркетингова діяльність у тих країнах, куди проник бізнес, } \\
\text { допомагаючи компанії зрозуміти зовнішній ринок, та щоб зробити } \\
\text { бізнес-політику відповідною до того середовища, в яке вона } \\
\text { проникла. }\end{array}$ \\
\hline $\begin{array}{l}\text { Глобальний маркетинг } \\
\text { (багатонаціональний) }\end{array}$ & $\begin{array}{l}\text { країні, з певния здійснює діяльність або операції в більш ніж одній } \\
\text { межами тієї країни, в якій фактично продаватимуться товари } / \\
\text { послуги. Вся організація фокусустся на виборі та використанні } \\
\text { глобальних маркетингових можливостей та збирає ресурси по } \\
\text { всьому світу з метою досягнення глобальної конкурентної переваги }\end{array}$ \\
\hline
\end{tabular}

Крім того, глобальний маркетинг представляє прагнення фірми координувати свою маркетингову діяльність за межами країни, щоб знайти і задовольнити глобальні потреби споживачів краще, ніж конкуренти, тому фірма здатна:

- розробити глобальну маркетингову стратегію, засновану як на подібності, так і на різниці між ринками;

- використовувати знання штаб-квартири (домашньої організації) через всесвітнє розповсюдження (навчання) та адаптацію;- передавати знання та найкращі практики між міжнародними ринками, що обслуговуються [17] .

Глобалізація змінює конкурентне середовище, в якому компанії повинні визначати маркетингову стратегію. Зростаюче використання електронної комерції, розповсюдження таких технологічних драйверів, як Інтернет та мобільні телефони, вдосконалення засобів транспортування та усунення політичних та економічних кордонів у багатьох регіонах світу дозволяє компаніям зосередитися не лише на внутрішніх ринки, але також різноманітні світові ринки.

Міжнародна стратегія - це стратегія компанії, яка реалізує бізнес-стратегію на всіх іiі внутрішніх та зовнішніх ринках шляхом переведення цінних навичок та продуктів на зовнішні ринки, де місцевим конкурентам не вистачає цих навичок чи продуктів. Міжнародний бізнес - це процес планування, організації, керівництва та перевірки міжнародної ділової діяльності 3 метою досягнення цілей, встановлених у раціональному та економічному використанні наявних ресурсів [12].

Оскільки глобальні ринки 3 часом стають більш взаємопов'язаними та динамічними, ефективний моніторинг зовнішнього середовища та максимальне використання специфічних ресурсів компанії будуть обов'язковими для отримання конкурентних переваг. Виникає потреба у 
розробці ефективної маркетингової стратегії. Як стверджує Є. Горська, глобальний маркетинговий менеджмент - це ще більша та більш складна міжнародна операція, коли компанія координує, інтегрує та контролює цілу серію маркетингових програм у значні глобальні зусилля. Основною і головною метою компанії тут є досягнення певного рівня синергії в загальній роботі, так що організація в цілому буде більшою за суму іï частин, використовуючи різні обмінні та податкові ставки, ставки праці, рівень кваліфікації та ринкові можливості [17]

Ряд дослідників [11-14] стверджують, що глобальна маркетингова стратегія впливає на загальну ринкову ефективність фірми. Глобальна маркетингова стратегія, у свою чергу, опосередковується зовнішніми ринковими та внутрішніми драйверами, які фактично є внутрішніми характеристиками фірми. Ті фірми, котрі здатні «читати» та розуміти ці драйвери, швидше за все, працюватимуть ефективно. Фірмам, які діють у всьому світі, важливо швидко та ефективно реагувати на зміни в економіці, конкуренції, вимогах споживачів та технологіях. Бойкот французького вина у Сполучених Штатах на короткий час протягом 2003 року через опозицію Франції вторгненню американських збройних сил в Ірак та бойкот проти датської продукції в країнах Близького Сходу, спричинений датською кризою мультфільмів Мохаммеда в 2005 році, демонструє важливість збереження вух, відкритими для таких змін. Так само успіх фірми залежатиме від того, наскільки вона розвиває внутрішні можливості та ресурси для реалізації своєї стратегії. Потрібні менеджери, які одночасно усвідомлюють важливість інтернаціоналізації фірми і яким вдається реалізувати глобальну маркетингову стратегію [11]. Виходячи з вищенаведеного, ми пропонуємо власне бачення процесу міжнародного маркетингового стратегічного планування (рис.1).

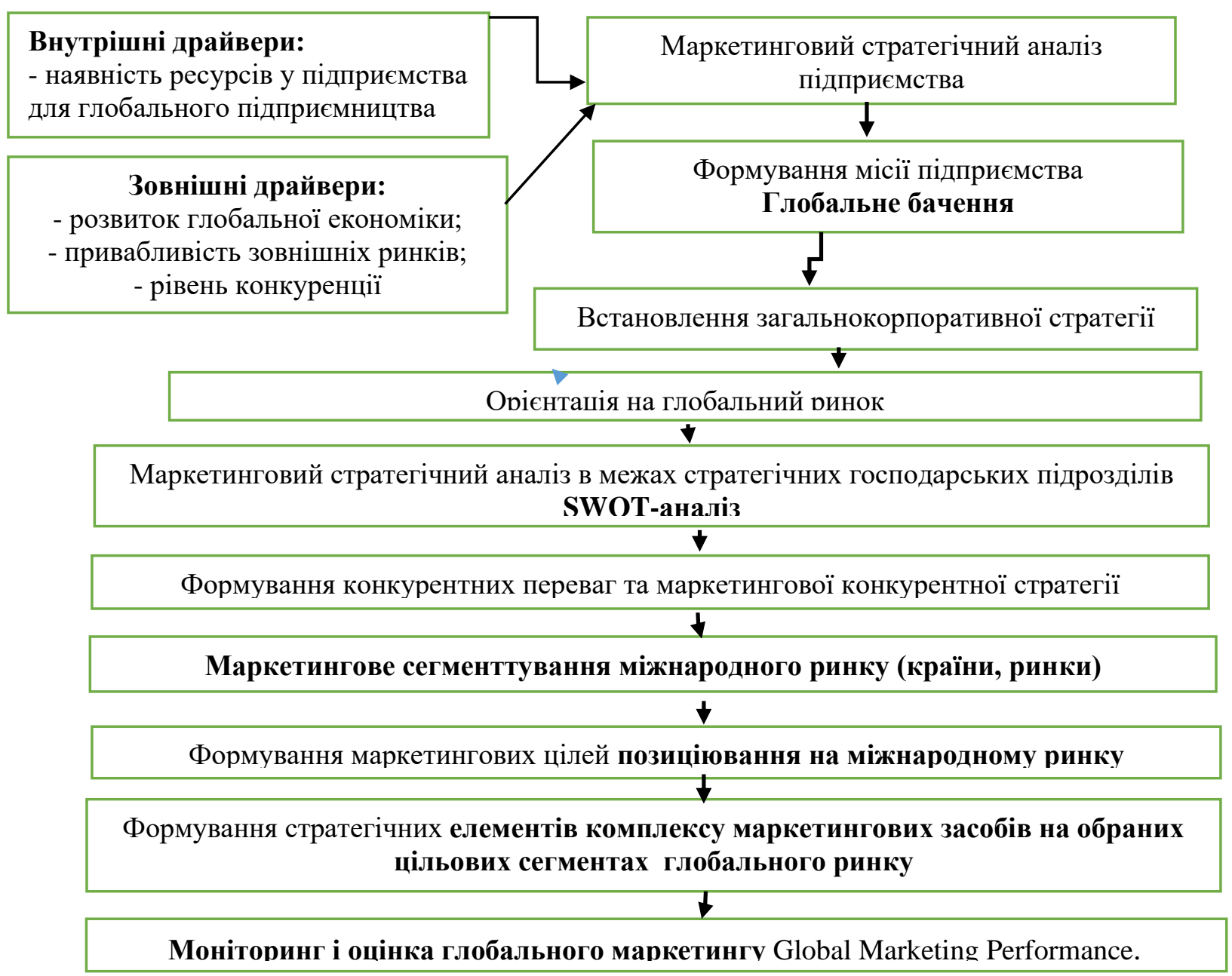

Рис. 1 Процес міжнародного маркетингового стратегічного планування Джерело: Розроблено автором за: [12-14] 
Якщо глобальна стратегія - це план для всієї організації, розроблений, щоб дозволити фірмі розвинути сильну глобальну присутність, особливо 3 погляду маркетингу та виробництва. Внутрішні драйвери - це ті, що походять від фірми i, таким чином, контролюються керівництвом, такими як глобальне бачення та можливості фірми, а також фінансування та міжнародний досвід керівників. 3 іншого боку, зовнішні драйвери не контролюються фірмою, але впливають на їі здатність визначати та виконувати глобальну стратегію.

Світові фірми постійно мають справу з парадоксом. 3 одного боку, глобальне охоплення передбачає загальні цілі та навички, які перевершують будь-яку конкретну країну. Дійсно, фірма може в'їхати в країну, оскільки ії бачення та досвід можуть використовувати більше виробничих ресурсів цієї країни, ніж місцеві фірми. 3 іншого боку, світові фірми зустрічаються з проблемами, викликаними несприйняттям місцевих ринків бізнес-політики іноземних компаній. Успіх означає адаптацію загальних знань до конкретних обставин кожної країни. Стратегічний виклик вступу глобальної фірми в нову країну полягає у визначенні бізнес-тактики та практики імпорту, розвитку на місці та способу їх поєднання в рамках працюючого глобального підприємства [11]

Основним моментом оцінки успіху глобального маркетингу є репутація товарного бренду, який люди пам'ятають і в який вірять та який показує свою ділову стійкість. Завдяки глобальному маркетингу, що включає всі маркетингові стратегії, застосовується однакова маркетингова стратегія міжнародних компаній на всіх ринках у світовому масштабі, наприклад, L'Oréal Group застосувала цю стратегію. Проникаючи на китайський ринок, L'Oréal Group зрозумів, що інші корпорації, 3 таких країн як Корея, Японія, розуміли поняття китайських жінок про красу. «Просто біла шкіра, усі дефекти покриті» - це девіз, що охоплює попит. Тому L'Oréal випустив асортимент косметичної продукції, яка спеціалізуються на виготовленні товарів, що роблять шкіру білішою, наприклад, тональний крем, коректор, щоб допомогти сучасним жінкам, які сьогодні живуть досить насиченим життям, заощадити свій час під час вибору косметики [17 ].

Маркетингові стратегії в іноземній країні залежать від культури, і те, що працює на ринку однієї країни, не обов'язково повинно працювати в іншій. У багатьох випадках, коли цільові клієнти належать до різних культурних середовищ, потрібна адаптація комплексу маркетингу. Очевидно, що пристосування до культурних імперативів, таких як мова, для забезпечення спілкування $\epsilon$ обов'язковим для кожної ділової діяльності. 3 іншого боку, пристосування до інших культурних елементів, не критичних для успіху, лише збільшує витрати та зменшує економію на масштабі та розмірі. Тому, ретельно проаналізувавши культурні імперативи, які існують на ринках, міжнародний маркетолог повинен лише адаптуватися до них. Можливо, доведеться змінити не лише застосування маркетингових інструментів, але навіть весь маркетинговий підхід може також бути адаптованим, якщо категорії мислення суттєво відрізняються від одного суспільства до іншого.

Дедалі частіше міжнародні менеджери 3 маркетингу повинні усвідомлювати, що культура не лише впливає на їх рішення, але й те, як їх рішення та дії впливають на культуру. Однак у багатьох випадках може бути важко передати маркетингові символи, торгові марки, логотипи та навіть продукцію на міжнародні ринки, особливо якщо вона пов'язана з об'єктами, які мають унікальне значення в певній культурі.

Глобальний підхід вимагає від фірми зосередити свої зусилля у всьому світі, а не розробляти маркетингові стратегії на основі окремих країн. Це також вимагає координації та інтеграції виробництва, збуту та інших функціональних видів діяльності в різних країнах. Для багатьох фірм глобальна маркетингова стратегія вимагає централізованої операції, щоб використовувати переваги масштабу, оптимізувати ресурси та зменшити витрати.

Міжнародний маркетинг відіграє дуже важливу роль «як центр дослідження, прогнозування та розробки стратегій збуту продукції на ринку країн-імпортерів». Там, де адаптація товарів бренду, просування та збір інформації є важким, маркетинг зближує споживачів та виробників, отримуючи зворотній зв'язок із клієнтами, щоб задовольнити максимальні потреби споживачів. Таким чином, стає одним з одне 3 найбільш ефективних засобів конкуренції на міжнародному ринку» [10]. Маючи цінні унікальні можливості, компанії часто можуть досягти величезного обсягу продажу, 
використовуючи ці унікальні можливості та виробляючи продукцію для зовнішніх ринків, де місцеві конкуренти не мають можливості виробляти подібну продукцію.

Адаптацію підприємницької діяльності підприємств до умов глобального середовища, яке випливає з великої різниці між зовнішнім та внутрішнім ринками доцільно реалізовувати через виконання таких функцій:

- створення системи спостереження за глобальними ринками, щоб швидко і точно визначити коливання ринку або, за можливості, заздалегідь прогнозувати їх;

- моніторинг результатів та перевірка заходів з подолання труднощів, які виникають під час роботи через відмінності в методах ведення обліку та культурних середовищах різних країн.

Виконання цих функцій $є$ необхідною умовою довгострокового та ефективного глобального розвитку підприємств.

Висновки та перспективи подальшого дослідження. Міжнародний маркетинг виконує такі основні функції: дослідження ринків споживання; пристосування та здатність швидко реагувати на умови ділового середовища, розробляти бізнес-плани та контролювати результативність, кількісно оцінювати труднощі, що виникають в управлінні бізнесом; запропонувати ефективні заходи щодо збору інформації та здійснення підприємницької діяльності на кожному ринку. У всіх країнах бізнес завжди застосовує міжнародні маркетингові стратегії. однак по-різному. Завдяки застосуванню ефективних міжнародних маркетингових стратегій компанії на ринку досягли певного успіху. Це необхідні умови для довгострокового розвитку і високої ефективності глобального підприємництва.

На основі маркетингових стратегій пропонуємо виконувати такі заходи щодо покращення глобального підприємництва: вишукувати відмінності у стратегіях постачання та збуту щоб відповідати місцевому середовищу та вимагати передачі виробничої та маркетингової діяльності місцевим філіям. Це допоможе зменшити тиск через глобалізацію, сучасні інформаційні технології та транспорт. Хоча це призведе до збільшення витрат зараз, але дозволить отримати більше прибутку в майбутньому.

\section{Джерела та література}

1. Кальченко Т. В. Глобальна економіка: методологія системних досліджень: монографія. К.: КНЕУ, 2006. $248 \mathrm{c}$.

2. Ковінько О. М. Маркетинг в умовах міжнародної диверсифікації бізнес-діяльності: монографія. К. : КНЕУ. 2017.

3. Концепти інноваційного розвитку підприємництва : монографія . Київ: Інтерсервіс, 2018. 263 с

4. Корж М. В. Механізм управління інструментарієм міжнародного маркетингу: теорія і практика: монографія. Краматорськ: ДДМА, 2011. 336 с.

5. Проданова Л. В. Мотиваційний механізм розвитку підприємницької діяльності в економіці України: монографія. Черкаси. : Видавець Пономаренко Р.В., 2019. 240 с

6. Розвиток маркетингу в умовах глобалізації: сучасні тенденції та перспективи: монографія. Тернопіль: ТНТУ ім. І. Пулюя, 2015. - 411 с.

7. Супрун С. Д. Етапи формування міжнародної маркетингової стратегії підприємств. Вінницький торговельно-економічний інституm «Young Scientist» № 8 (35) august, 2016 [Електронний ресурс] : Режим доступу: http:// molodyvcheny.in.ua/ files/journal/2016/8/10.pdf

8. Філіпенко А. С. Україна і світове господарство. Взаємодія на межі тисячоліть. навч. посіб. К.: Либідь, 2002.

9. Циганкова Т. М. Міжнародний маркетинг: теоретичні моделі та бізнес-технології: монографія. К.: KHEУ, 2004. 400 c

10. Hoang T. N., Phu P. P., Chi Ph. D. T. The role of international marketing in international business strategy. N.H. Tien, [Електронний ресурс] : Режим доступу: https:// www.academia.edu/ 2588463/ Global_Marketing_Contemporary_Theory_Practice_and_Cases

11. Smart marketing and marketing // Global Marketing: Contemporary Theory, Practice and Cases [Електронний ресурс] :- Режим доступу: https://www.academia.edu/2588463/Global_Marketing_Contemporary_Theory_Practice_and_Cases

12. Sheth J.The antecedents and consequences of integrated global marketing / J. Sheth, A. Parvatiyar // International Marketing Review, 2001 № 18(1), p.16-34. 
13. Quelch J. A.Customizing global marketing / J. Quelch, E. J. A. Hoff //Harvard Business Review. 1986 MayJune, № 64, p.59-68 29.

14. Douglas S. P., Y. Wind. The myth of globalization. Columbia Journal of World Business. 1987, Winter p.19-

15. Horská E. International marketing within and beyond visegrad borders. 2014 [Електронний ресурс] :Режим доступу: http://centre.uek.krakow.pl/CENTRUMPSiM/wp-content/ uploads/ 2017/ 10/Horska_et_al_2014_mini.pdf

\section{References}

1. Kal`chenko T. V. (2006) Global`na ekonomika: metodologiya sy`stemny`x doslidzhen`: monografiya [Global economics: methodology of systemic dosages: monograph] K.: KNEU [in Ukrainian].

2. Kovin`ko O. M. (2017). Markety`ng v umovax mizhnarodnoyi dy`versy`fikaciyi biznes-diyal`nosti: monografiya [Marketing in the minds of international diversification of business activities: monograph] K.: KNEU [in Ukrainian].

3. Xrapkina V.V. (Eds.) (2018) Koncepty innovacijnogo rozvytku pidpryyemnycztva: monografiya [The concept of innovative development of the enterprise: monograph] Nacional'nyj universytet «Kyyevo-Mogylyans`ka akademiya». - Ky`yiv: Interservis [in Ukrainian].

4. Korzh M. V. (2011) Mexanizm upravlinnya instrumentariyem mizhnarodnogo marketyngu: teoriya i praktyka: monografiya [Mechanism of management and tools for international marketing: theory and practice: monograph] Kramators`k: DDMA [in Ukrainian].

5. Prodanova L. V., \& Kotlyarevs`ky`j O. V. (2019) Motyvacijny`j mexanizm rozvytku pidpryyemnyczkoyi diyal'nosti v ekonomici Ukrayiny: monografiya [Motivational mechanism of development of industrial activity in the economy of Ukraine: monograph] Cherkas`ky`j derzhavn`j texnologichnyj universytet. - Cherkasy: Vydavecz Ponomarenko R.V. [in Ukrainian].

6. Fedorovych R. V. (2015). Rozvytok marketyngu v umovax globalizaciyi: suchasni tende-nciyi ta perspektyvy: monografiya [Promotion of marketing in the minds of globalization: current trends and prospects: monograph] Ternopil: TNTU im. I. Pulyuya, 2015. [in Ukrainian].

7. Suprun S. D., \& Stratijchuk V. M. (2016) Etapy formuvannya mizhnarodnoyi marketyngovoyi strategiyi pidpryemstv [At the same time the formulation of the international marketing strategy of enterprises] «Young Scientist» -Vinnytsia Trade and Economic Institute "Young Scientist" august, № 8 (35) [in Ukrainian].

8. Filipenko A. S. Luk'yanenko D. G., \& Poruchny`k A. M. (2002) Ukrayina i svitove gospodarstvo. Vzayemodiya na mezhi tysyacholit’. navch. posib. [Ukraine and statehood. Vzaemodya at the middle of a thousand years. navch. posib.] K.: Lybid

9. Cygankova T. M. (2004). Mizhnarodnyj marketyng: teoretychni modeli ta biznes-texnologiyi: monografiya.[ International marketing: theoretical models and business technologies: monograph]. K.: KNEU

10. Tien N. H., Phu P. P., \& Chi D. T. Ph (n.d) The role of international marketing in international business strategy / Retrieved from:https:// 2588463/ Global_Marketing_Contemporary_Theory_Practice_and_Cases [in England].

11. Smart marketing and marketing (n.d) Global Marketing: Contemporary Theory, Practice and Cases Retrieved from: https://www.academia.edu/2588463/Global_Marketing_Contemporary_Theor_Practice_and_Cases[in England].

12. Sheth J., \& Parvatiyar A. (2001) The antecedents and consequences of integrated global marketing / International Marketing Review № 18(1), p.16-34. [in England].

13. Quelch J., Hoff E. J. A. (1986) Customizing global marketing Harvard Business Review. 1May-June, № 64, p.59-6 8[in England].

14. Douglas S. P., \& Wind Y. (1987) The myth of globalization Columbia Journal of World Business Winter p.19-29. [in England].

15. Horská E. ( 2017) International marketing within and beyond visegrad borders Wydawnictwo episteme in Krakow, Retrieved from: http:// centre.uek.krakow.pl/ CENTRUMPSiM/ wp-content/ uploads/ 2017/ 10/Horska_et_al_2014_mini.pdf[in England]. 